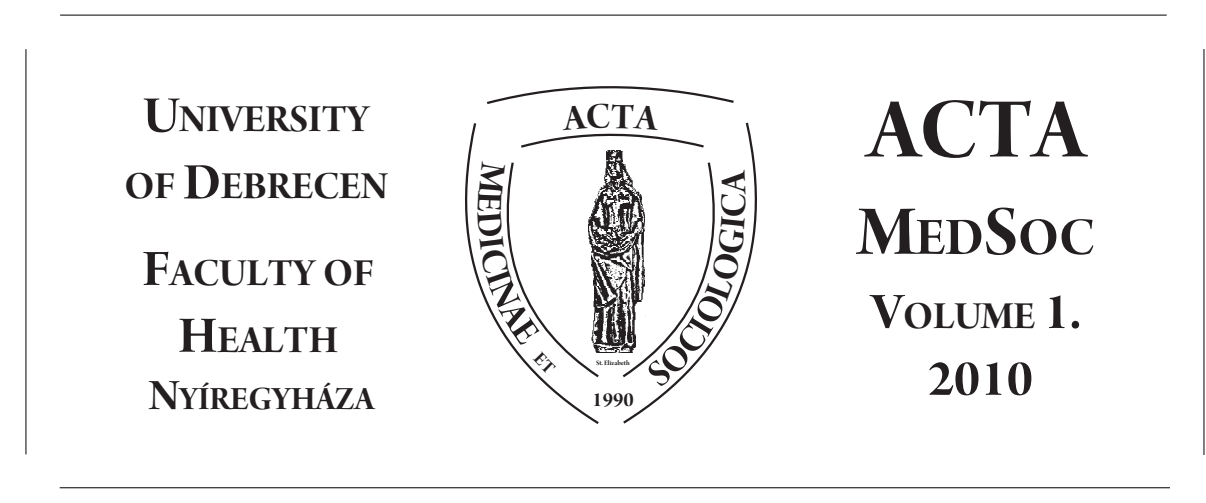

\title{
Peculiarities and statistical investigation of food consumption Ukraine
}

\section{Andras Kulja ${ }^{1,2}$, Mariia Mudryk ${ }^{1}$, Taissiya Symochko ${ }^{1}$, Larysa Bugyna ${ }^{1}$, Nelya Koval ${ }^{1}$, Anna Tereshchenko ${ }^{3}$, Nadiya Boyko ${ }^{1}$}

1 Uzhhorod National University, MESU, Department of Microbiology, Immunology, Virology with Etiology of Infectious Diseases, Ukraine; 2 University of Debrecen, Faculty of Health, Hungary; 3 Institute of Demography and Social Study, NASU, Ukraine.

e-mail: kulja@de-efk.hu

\begin{abstract}
Statistical data relevant to food consumption, morbidity and mortality of the last ten years has been examined and discussed.

Keywords: food consumption, statistic data, nutrition

DOI: $10.19055 / \mathrm{ams} .2010 .1 / 1 / 4$

Lektor: Dr. Szabó Judit Ph.D, egyetemi docens, DEOEC ÁOK

\section{Introduction}

It is generally accepted that the way of life determines approximately $50 \%$ of population' health conditions. Unhealthy diet, poor lifestyle, unsaved working and leaving conditions, polluted environment, steady stress combined with insufficient education and culture are the most important risk factors negatively influenced on human body.
\end{abstract}


Under the present political instability and worldwide crisis the question has to be answered is how above mentioned factors affect the nutrition and it in its turn affects on public health. Average of Ukrainians' lifetime keeps decline despite state programs' attempts to influence this process. Among the population of Ukraine the "hidden" malnutrition is highly registered as results of unbalanced and deficiency of vitamins, minerals with antioxidant action and other "minor" components of food, including flavonoids, biogenic amines, organic acids, and pigments [4, 9]. The Ukrainian diet is often based on consumption of cheap, useless, rich in carbohydrates food products $[4,6,7]$.

The alimentary quality and variety of food ingredients are determined by low capacity of majority of population to consume highly beneficial and healthy products due to different reasons what lead to the permanent disability of dietary pattern formation [8]. Correspondingly in last decades the enormous increasing of diseases and decays relevant to misbalanced nutrition had been observed. The obesity, type 2 diabetes mellitus, inflammatory bowel disease, celiac and cardiovascular diseases, arterial hypertension are the first in this list. In the same time, expenses of Ukrainians for the meal items are averaged by $53 \%$ of total household expenditure while abroad (in developed European countries and USA) they are limited to 20\% [5, 11]. According to the accepted by different independent sources criteria, one of the informative index for the population (country) poverty is the quota of expenditures for buying food over $50 \%[2,3,12]$.

Finally, inefficient nutrition is unprofitable process in economic, since lead to increasing of state and private costs for the diagnosis, treatment, after-treatment rehabilitation due to illness, and correspondingly to lowering of the income for families [12].

\section{Materials}

We examined and summarized the statistical data of food products' consumption in 2003, 2005 and 2007 years (kgyearperson) and in the years 1999-2008 (kgmonthperson) - consumption of different food components in dependence of place of the residency, income and in relevance to the mortality data (1990-2007). The analyzed numbers were obtained from the official website of the State Statistics Committee of Ukraine (Derzhcomstat) [1].

\section{Methods}

The sampling formation was based on a stratified multistage selection procedure that consists of the following basic steps: 1) the exclusion of areas that cannot be examined; 2) the exclusion of the population that is not a subject of examination; 3) the stratification of the general population; 4) the selection of territorial units; 
5) the selection of households. The sampling formation procedure was two-stage in urban areas and three-stage in the countryside.

The sources were: 1) demographic statistic data base at the beginning of the reporting year (the number of resident population by region and type of terrain; sex and age population structures by region in terms of the following age groups: women and men aged 18 years; $18-35$ years; $36-59$ years and in the disabled age); 2) the statistical reports on population, which was institutional facilities possession.

Every year approximately 13 thousand addresses of households in Ukraine are selected for participating in the survey.

\section{Results}

The one of the aim of this study is to explore the differences of calorie and food components (protein, fat, carbohydrates) consumption depending on place of residence - rural or urban areas (Fig. 1). As shown on Fig. 1 the statistics data of 2007 suggest that urban households consumed higher amount of lipids in food products. The increased level of cholesterol has adversely affects on health and induces the development of hyperlipidemia, general atherosclerosis, coronary heart disease (CHD), hypertensive disease and other widespread heart diseases).

The population of rural areas consumes more calories, proteins and carbohydrates than the urban citizens although the slightly difference in consumption between them. Also we have examined the differences in the consumption of the same components of food and calories, but depending on their income. For better insight into the subject we highlight two characters - line of the "poverty" and minimum of the salary in this year. One could note that poverty line was higher than the minimum wage in 2007 and the Fig. 2 is clearly demonstrates that consumption of various food components is in direct proportion that depends on income level: the lower level of income the less nutrients is consumed and the higher deficiency has occurred.

In Fig. 3 the consumption (kg/year/person) of food within different categories, recommended standards and degree of deficiency during 2003, 2005 and 2007 year presented. As seen from the analyses of these statistical data the optimal situation is stated if the actual food consumption by a person for a year equal to the rational/recommended norm, i.e., correspondingly correlation coefficient between the actual and reasonable consumption is close to 1 .

As you can see, real consumption is very different from the rational norms of healthy food. In Ukraine in 2007 for most types of food an actual consumption was found below the rational norms. Problem concerns to almost all types of food, except sugar, which ranges from $5 \%$ of the recommended standards. It is difficult to make any conclusion about the consumption of eggs and oil, as in different years it was different. Positive trend should be noted: the decreasing of cereal products and potatoes consumption is observed. Situation with meat and dairy products, 


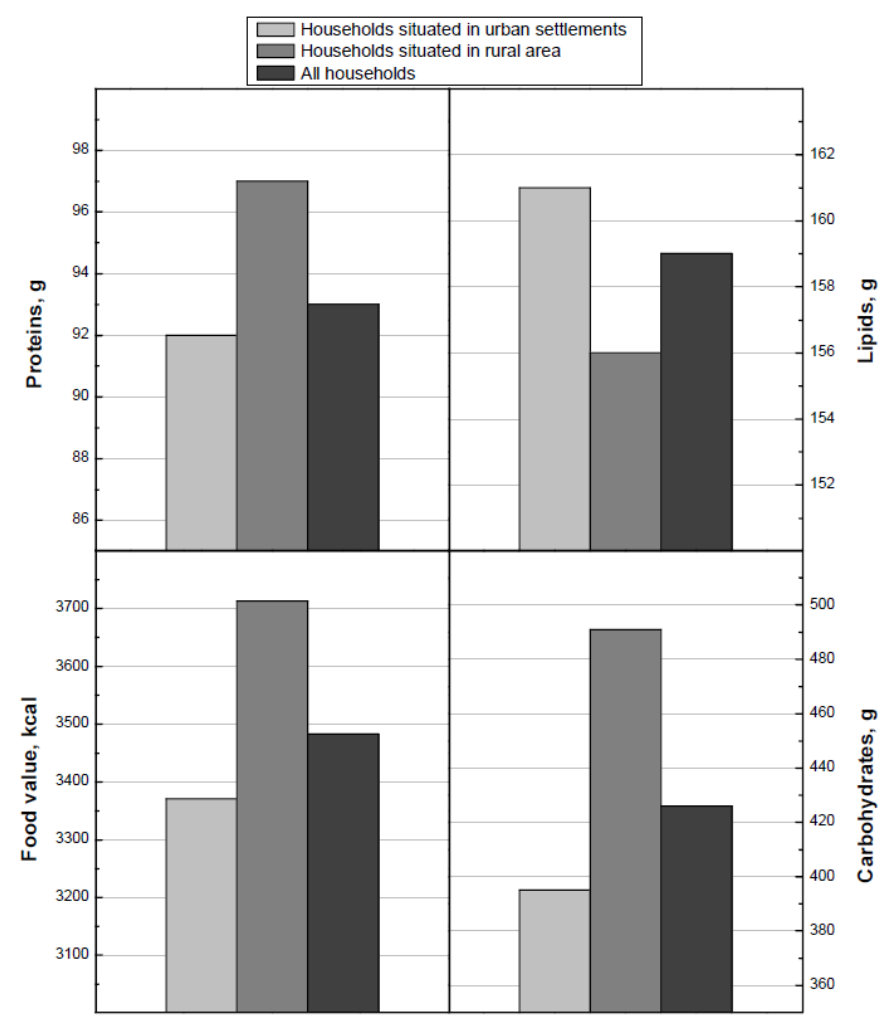

Figure 1: Food value and nutrients in food consumed in households in terms of place of residence (average per day per person, 2007).

fruits, berries, nuts, grapes is on critical level: deficit of their consumption is more than $40 \%$.

Despite the fact that Ukrainians consumed meat and fish under the recommended rational norms, there is the dangerous tendency to decrease it in 2007 as compared to 2003. Milk consumption remains insufficient to approximately the same level during 2003-2007. Greengrocery usage is significantly low including the consumption of fruits.

Situation of food consumption during 1999 - 2008 ( $\mathrm{kg}$ per month per person) could be characterised as tendency for the improving the ratio between normal nutritional needs and real consumptions (Fig. 4). As demonstrated on Fig. 4 consumption of meat, milk, eggs, fish, fruits has been increased. Expansion of above mentioned food products leads to the lowering in consumption of potatoes and bread. One can assume that consumption of vegetables is varies in different years. 


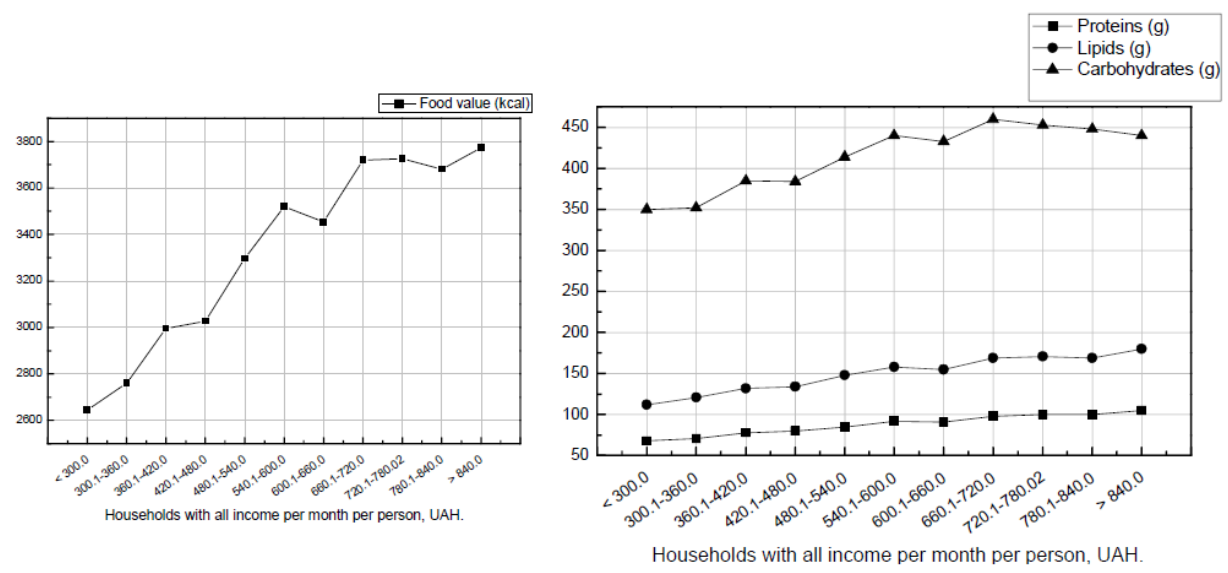

Figure 2: Food value and nutrients in food consumed in households in terms of personal income (average per day per person) in 2007; Minimum salary as of October 1, 2007 was $460 \mathrm{UAH}$, subsistence level October 1, 2007 was 532 UAH.

Note: Deficits are highlighted.

Nutrition, quality of life and lifetime are interrelated factors. Unfortunately, mortality is steadily high in Ukraine. The main structure: almost half of total mortality caused by cerebral-vascular and heart diseases in the years 1990-2006 (Fig. 5). The others deaths are resulted by malignant neoplasm, poisonings and injuries, diseases of respiratory system, accidents (Fig. 5). The classification of the deaths is carried out in accordance with International Statistical Classification of Diseases (10th revision) approved in 2005.

As it seen in Fig. 5, heart diseases are still the main cause of death. It is needed to be admitted additionally that Ukrainians are dying earlier compared to people from economically developed countries. This is indices also could be treated as indicators of population adaptation to new socio- economic conditions.

\section{Discussion}

Only in four positions, namely: bread, potatoes, oil and sugar actual consumption in Ukraine exceeded the rational norm. However, such exceeding on the noted groups of food, especially bread products and potato is the evidence of unbalanced diet of population, which tries to provide own energy necessities through more economically available products. The biggest gap of actual consumption from rational 


\begin{tabular}{|c|c|c|c|c|c|c|c|}
\hline $\begin{array}{l}\text { The basic } \\
\text { foodstuff }\end{array}$ & $\begin{array}{l}\text { Rational } \\
\text { norms of } \\
\text { healthy } \\
\text { food }\end{array}$ & $\begin{array}{l}\text { Real } \\
\text { consumption } \\
\text { in } 2003\end{array}$ & $\begin{array}{l}\text { Deficiency } \\
\text { of food } \\
\text { consumption } \\
\text { in } \mathbf{2 0 0 3}\end{array}$ & $\begin{array}{l}\text { Real } \\
\text { consumption } \\
\text { in } 2005\end{array}$ & $\begin{array}{l}\text { Deficiency } \\
\text { of food } \\
\text { consumpti } \\
\text { on in } \mathbf{2 0 0 5}\end{array}$ & $\begin{array}{l}\text { Real } \\
\text { consumption } \\
\text { in } \mathbf{2 0 0 7}\end{array}$ & $\begin{array}{l}\text { Deficiency } \\
\text { of food } \\
\text { consumption } \\
\text { in } \mathbf{2 0 0 7}\end{array}$ \\
\hline \multicolumn{3}{|c|}{$\mathrm{kg} /$ year/person } & $\%$ & $\mathrm{~kg} /$ year/person & $\%$ & $\mathrm{~kg} /$ year/person & $\%$ \\
\hline Meat products & 83 & 34,5 & $-58,4$ & 39,1 & $-52,9$ & 45,7 & $-44,9$ \\
\hline $\begin{array}{l}\text { Dairy } \\
\text { products }\end{array}$ & 380 & 226,4 & $-40,4$ & 225,6 & $-40,6$ & 224,6 & $-40,9$ \\
\hline Eggs (pieces) & 290 & 214 & $-26,2$ & 283 & $-2,4$ & 252 & $-13,1$ \\
\hline $\begin{array}{l}\text { Fish and fish } \\
\text { products }\end{array}$ & 20 & 12,0 & $-40,0$ & 14,4 & -28 & 15,3 & $-23,5$ \\
\hline $\begin{array}{l}\text { Bread } \\
\text { products }\end{array}$ & 101 & 124,5 & 23,3 & 123,5 & 22,2 & 115,9 & 14,8 \\
\hline Potatoes & 124 & 138 & 11,3 & 135,6 & 9,4 & 130,4 & 5,2 \\
\hline $\begin{array}{l}\text { Vegetables, } \\
\text { melons and } \\
\text { gourds }\end{array}$ & 161 & 113,6 & $-29,4$ & 120,2 & $-23,3$ & 118,4 & $-26,5$ \\
\hline $\begin{array}{l}\text { Fruits, berries } \\
\text { and grapes }\end{array}$ & 90 & 33,0 & $-63,3$ & 37,1 & $-58,5$ & 42,1 & $-53,2$ \\
\hline Sugar & 38 & 36,4 & $-4,2$ & 38,1 & 0,26 & 40,0 & 5,3 \\
\hline Oil & 13 & 11,3 & $-13,1$ & 13,5 & 3,8 & 14,3 & 10 \\
\hline
\end{tabular}

Figure 3: Food consumption in Ukraine in 2003, 2005, 2007 (kg/year/person).

norm observed in milk and dairy products, meat and meat products, fruit, berries and grapes.

Demographic situation in Ukraine remains difficult. There are no objective grounds for the suspension of the existing trend of reducing the total population. Government policy should be aimed primarily at increasing and improving the quality of life.

\section{Literature}

1. Data of State Statistics Committee of Ukraine [http://www.ukrstat.gov.ua/], in Ukrainian.

2. Titarenko O. M. Forming of a regional vegetable sub-complex in condition of transformation to market economy [http://www.nbuv.gov.ua/e-Journals/nd/20061/06tomtme.pdf], in Ukrainian.

3. Rud' V. P. Features of concentration and specialization in vegetable industry / Rud' V. P. // Economics AIC. - 2001. - №5. - С. 94-97. [Рудь В.Р. Особливості концентрації та спеціалізації в овочівництві / В. П Рудь // Економіка АПК. 2001. - №5. C. 94-97]. - in Ukrainian.

4. Pysarenko V. V. Providing people with fresh and processed produce under adverse external and internal environment is one of the major problems of modern food market [Писаренко В.В. Забезпечения населения свіжою та переробленою плодоовочевою продукцією в умовах несприятливого зовнішнього та внутрішнього середовища $\epsilon$ одніэю з найважливіших проблем сучасного продо- 

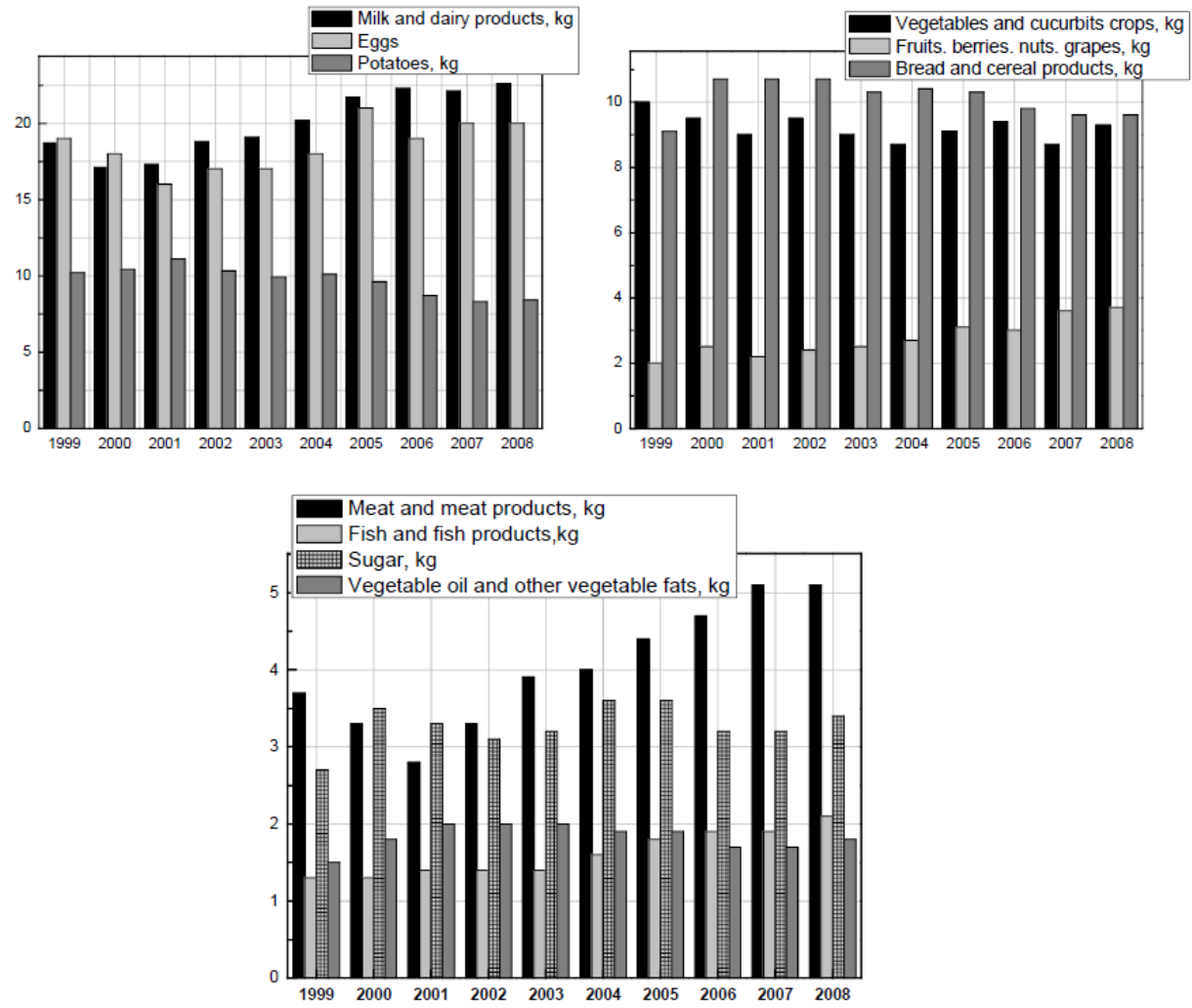

Figure 4: Consumption of food in households in 1999-2008 (average per month per person).

вольчого ринку] [http://www.agromage.com/stat_id.php?id=325], in Ukrainian. 5. Rud' V.P. Formation and effective functioning of the regional market vegetable production. Autoref. Diss. Cand. Of econ. Sci., 2006. - 27 p., in Ukrainian [Рудь В.П. Хормування та ефективність функціонування регіонального ринку овочевої продукції: дис. канд. екон. наук: 08.07.02 / Харківський національний аграрний універцитет ім В.В. Докучаєва - X. 2006. - 27c.], in Ukrainian.

6. Davydenko N. V. Dynamic features of nutrition and alimentary risk factors of cardio vascular diseases in the male population according to the 25-year monitoring / N. V. Davydenko // Nutrition problems. - 2008. - № 1-2. - P. 20-27. [Давиденко Н.В. Динаміка особливостей харчування та аліментарнозалежних факторів ризинку серцево судинних захворювань в чоловічій популяції за даними 25-річного моніторингу / Н.В. Давиденко // Проблеми харчубання. 2008. №1-2. C. 20-27], in Ukrainian. 

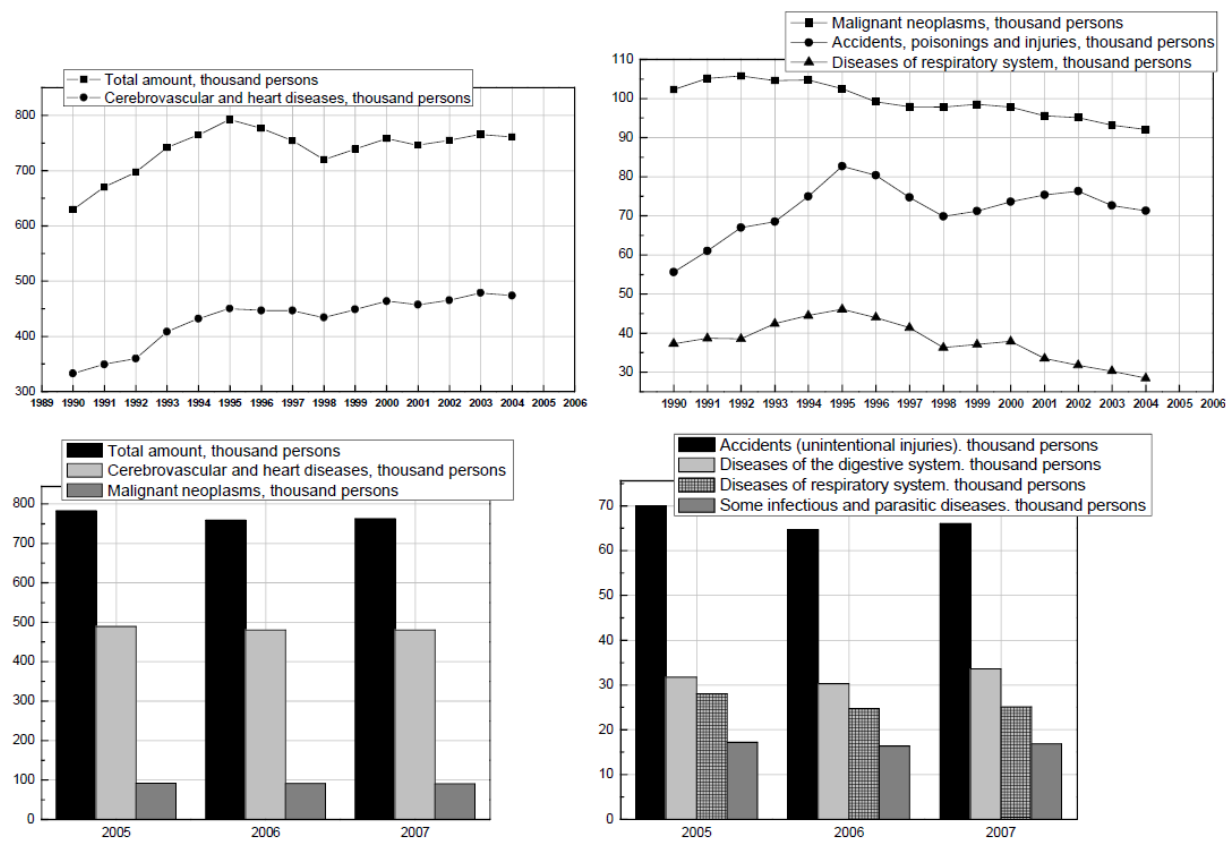

Figure 5: Mortality structure in Ukraine during 1990-2004 and 2005-2007 years.

7. Heorhievskiy V. P. Biologically active substances in medicinal plants / Heorhievskiy V. P., Komissarenko N. F., Dmytruk S. E. // Novosibirsk : Science, 1990. - 333 р. [Георгиевский В.П. Биологически актвные вещества лекарственных рацтений / В.П. Георгиевский, Н. Ф. Комиссаренко, С. Е. Дмитрук // Новосибирск: «Наука», 1990. - 333 ст.], in Russian.

8. Hruzyeva T. S. Nutrition of Ukrainian population groups in the current conditions of society stratification / T. S. Hruzyeva // Nutrition problems. - № 4 . - 2004. [Грузєва Т. С. Харчування різних груп населення України в сучасних умовах статифікації суспільства / Т. С. Грузєва // Проблеми харчування. - №4. - 2004], in Ukrainian [http://www.medved.kiev.ua/arh_nutr/ art_2004/ n04_4_6.htm].

9. Moskalenko V. F. Features Food Population of Ukraine and Their impact on Health / V. F. Moskalenko, T. S. Hruzyeva, L. I. Halienko // Scientific Bulletin of the National Medical University in the name of O. O. Bohomolets. - 2009. - № 3. - Ń. 64-73. [Москаленко В. Ф. Особливості харчування населення України та їх вплиб на здоров'я / В. Ф. Москаленко, Т. Ф. Грузєва, Л. І. Галієнко // Науковий бісник національного медичного університету імені О. О. Боломольця. - 2009. - №3. - С. 64-73], in Ukrainian. 
10. Podryhalo L. V. Current priorities and prospects of scientific and practical research in nutritiology / L. V. Podryhalo, N. M. Filatova, R. S. Nazaryan // Medical practice. - 2007. - № 1 (55). - Р. 103 - 107. [Подрыгало Л. В. Современные приоритеты и перспективы научно-практических исследований в нутрициологии / Л. В. Подрыгало, Н. М. Филатова, Р. С. Назарян // Врачебная практика. 2007. №1 (55). - C. 10 - 107], in Ukrainian.

11. Shangina L. Structure of households income and expenditure does not felt the crisis / L. Shangina, V. Yurchyshyn // Macroeconomical Review of Ukraine. - December, 2009. [Шангіна Л. Структура доходів і витрат домогосподарств "не бідчула" кризи / Л. Шангіна, В. Юрчишин // Макроекономічний огляд України. - Грудень, 2009], in Ukrainian [http://www.razumkov.org.ua/ upload/ yurchyshyn_shanhina_ohliad_XIIP -2009.pdf].

12. Futalo T. V. Characteristics and trends of modern development in the rural consumer goods market / T. V. Futalo // Research Bulletin of Ukrainian State Forestry University. - 2004. - Vol. 14.4. - Р. 161-170. [Футало Т. В. Характеристика та тенденції сучасного розвитку сілъського ринку споживчих товарів / Футало Т. В. // Український державний лісотехнічний універцитет, Науковий вісник. - 2004. Вип. 14.4. - С. 161-170], in Ukrainian.

\section{Adrás Kulja}

This study was founded under the EU FP7 Theme 2: "Food, agriculture, fisheries, and biotechnology", Grant Agreement no: 227118, and partially supported by the National Office for R\&T of Hungary (UA-5/2008) and Ministry of Education and Science of Ukraine (M27-2009-HU). 